\title{
ASPECTOS DA SEDIMENTAÇÃo dA FORMAÇÃo RIO dO SUL (PERMIANO), NA REGIÃo dE RIO DO SUL, SC
}

J.R.Canuto

A Formação Rio do Sul, intervalo superior do Subgrupo Itararé (Permiano), na região centro-leste de Santa Catarina, inclui um complexo de facies representativas de condições glaciais, glácio-marinhas e marinhas.

$\mathrm{Na}$ parte basal da seção, depósitos descontínuos e delgados de tilito basal (de alojamento) e de fluxo recobrem o embasamento cristalino, moldado, polido, contendo estrias e marcas em crescente, demonstrando a presença de geleiras em condições aterradas (grounded), que atingiram a margem e adentraram a chamada depressão ou bacia de Rio do Sul.

0 tilito é encimado, em contato brusco, por folhelho escuro (Folhelho Lontras), contendo, nos seus primeiros metros, clastos dispersos, provavelmente caídos de icebergs, caracterizando uma sedimentação glácio-marinha, associada a raros fluxos de detritos, sob a forma de corpos tabulares, de até $\mathbf{4 0}$ centímetros de espessura, de diamictitos arenosos. A influência glacial diminui gradativamente para cima, com o desaparecimento dos clastos caídos, passando a predominąr condições marinhas típicas. A bacia passa, então, a receber pulsos turbidíticos, representados por ritmitos finos, indicativos de condições marinhas mais profundas.

Acima desse conjunto de sedimentos, ocorrem extensos corpos areníticos, com alguma estratificação cruzada acanalada, interpretados como depósitos fluvio-glaciais subaquáticos, ou, alternativamente, depósitos de canais fluviais atingindo a bacia de Rio do Sul, através da margem oeste. Essas facies passam, em direção às zonas de deposição mais profundas, a espessos depósitos de talude, sob a forma de turbiditos, fluxos de detritos e granulares de areia, limitados acima e abaixo por folhelho.

Departamento de Paleontologia e Estratigrafia, Instituto de Geociências, USP. 
Na parte superior da seção da Formação Rio do Sul, retornam as evidências de influência glacial, documentadas por espessos e extensos corpos de varvito, contendo abundantes clastos caídos, montículos e lentes de despejo e de aterramento, e estruturas de arrasto de icebergs. Lateralmente, condições de águas marinhas rasas são evidenciadas pela ocorrência de depósitos interlaminados de siltito/arenito fino e folhelho, de plataforma rasa ou de planície de maré, recobertos, em contato brusco, ou por transição, pelos arenitos fluvio-deltáicos da Formação Rio Bonito (Membro Triunfo).

A sucessão de facies reconhecidas sugere episódios alternados de avanço e recuo das geleiras e de variação do nivel do mar, durante a deposição da Formação Rio do Sul. 